\title{
Apocalypse yesterday: posthumanism and comics in the Anthropocene
}

Article

Accepted Version

Menga, F. and Davies, D. (2020) Apocalypse yesterday: posthumanism and comics in the Anthropocene. Environment and Planning E: Nature and Space, 3 (3). pp. 663-687. ISSN 2514-8486 doi: https://doi.org/10.1177/2514848619883468 Available at https://centaur.reading.ac.uk/87098/

It is advisable to refer to the publisher's version if you intend to cite from the work. See Guidance on citing.

To link to this article DOI: http://dx.doi.org/10.1177/2514848619883468

Publisher: SAGE Journals

All outputs in CentAUR are protected by Intellectual Property Rights law, including copyright law. Copyright and IPR is retained by the creators or other copyright holders. Terms and conditions for use of this material are defined in the End User Agreement.

\section{www.reading.ac.uk/centaur}

\section{CentAUR}

Central Archive at the University of Reading

Reading's research outputs online 


\title{
Apocalypse yesterday: posthumanism and comics in the Anthropocene
}

\author{
Filippo Menga, University of Reading, UK (f.menga@ @reading.ac.uk) \\ and \\ Dominic Davies, City, University of London, UK
}

\begin{abstract}
This is an Accepted Manuscript of an article published by SAGE in Environment and Planning E: Nature and Space [Article DOI 10.1177/2514848619883468].
\end{abstract}

\begin{abstract}
It is widely recognised that the growing awareness that we are living in the Anthropocene - an unstable geological epoch in which humans and their actions are catalysing catastrophic environmental change - is troubling humanity's understanding and perception of temporality and the ways in which we come to terms with socio-ecological change. This article begins by arguing in favour of posthumanism as an approach to this problem, one in which the prefix 'post' does not come as an apocalyptic warning, but rather signals a new way of thinking, an encouragement to move beyond a humanist perspective, and to abandon a social discourse and a worldview fundamentally centred on the human. The article then explores how the impending environmental catastrophe can be productively reimagined through graphic narratives, arguing that popular culture in general, and comics in particular, emerge as productive sites for geographers to interrogate and develop posthuman methodologies and narratives. Developing our analysis around two comics in particular - Here (McGuire, 2014) and Mad Max: Fury Road (Miller et al., 2015) - we show how graphic narrative can help us to move beyond the nature-society divide that is rendered anachronistic by the Anthropocene.
\end{abstract}

Keywords: Anthropocene, posthumanism, assemblage theory, comics, temporality.

\section{Introduction}

Questions relating to the formation of individual subjectivities through differences and sometimes binary distinctions are crucial to decoding our contemporary moment (Braidotti, 2003), marked as it is by increasingly polarised societal, economic and political debates. But if, as many geologists have proposed, we are now living in the age of the Anthropocene - an unstable geological epoch in which humans and their actions are the main driver of catastrophic environmental change (Rockstrom et al., 2009) - then this brings to the surface a contradictory condition in which anthropos is indissolubly embedded within, and increasingly pivotal to, the environment. Moreover, this works both ways: as 
Braidotti (2006: 197) notes, the notion of the human 'is not only de-stabilized by technologically mediated social relations in a globally connected world, but it is also thrown open to contradictory redefinitions of what exactly counts as human'.

These evolutionarily successive transformations of both our planet and its inhabitants are seen, by some observers (Asafu-Adjaye et al., 2015), as an opportunity for humans to use their 'extraordinary powers' to shape a 'good' Anthropocene. In this account, human ingenuity, science and technological advancement are viewed with an exceptionalism that is cause for optimism. Yet arguments claiming that the state of humanity as a whole has apparently never been better than it is today (Pinker, 2019) disregard the fact that millions of people still live in extreme poverty, and that inequality is rising (Lawson and Martin, 2018). Indeed, for most, environmental degradation and global warming - which are both an outcome and a reminder of humanity's inability to curb pollution and reduce its carbon emissions - foreshadow an approaching catastrophe that will diminish, if not devastate, life for future generations. The imagination of such disasters, which Davis (1999) appropriately calls an 'ecology of fear', manifests in increasingly urgent warnings about the risks of 'dangerous climate change' and a wide-ranging securitization of the environment (Dalby, 2009; Grove, 2010). Evoking images of the apocalypse to discuss global warming, a phenomenon essentially caused by economic growth and consumption (Kallis, 2011), is evidence of the indissoluble link between capitalism and its constant state of emotional crisis (Bruni, 2019). As the prevalence of apocalyptic narratives leads to its social and cultural normalisation, the environment is irremediably transformed into a problem that needs to be managed through various technical fixes. This proto-typically neoliberal discourse serves both to de-politicise environmental action and to disavow the fact that, for many people, the predicted crisis is already underway (Swyngedouw, 2013; Menga and Swyngedouw, 2018).

Predictions of the looming catastrophe are a telling example of our tendency to live temporality in a fundamentally subjective way, and this is what makes the Anthropocene so compelling. As Latour (2015: 149) observes, for the first time we live in an epoch in which our 'action modifies the very framework in which history is supposed to unfold', something that was unthinkable in the Holocene. In this conceptualisation of temporality, the future is no longer preceded by the present, but it is rather approaching, impacting upon, or even becoming the present. It is a terrible moment of reckoning, rendering our times as apocalyptic: the catastrophe matters, certainly, but perhaps what matters most is the revelation of exactly what that forthcoming catastrophe entails. This anagnorisis challenges both our spatial and temporal ontologies, bending Euclidean space to register as a kind of simultaneity, rather than linear chronology. This evolving socioecological landscape elicits a reflection on how we position ourselves as a civilisation towards and against this change, a stance that we argue can be fruitfully developed along the lines of the discourse of posthumanism, whereby the prefix 'post' does not come as an apocalyptic warning, but rather signals a new way of thinking, an encouragement to move beyond a humanist perspective, and to abandon a social discourse and a 
worldview fundamentally centred on the human. As Badmington (2004: 1345) puts it, an 'anthropocentric discourse relies upon a set of binary oppositions, such as human/inhuman, self/other, natural/cultural, inside/outside, subject/object, us/them, here/there, active/passive, and wild/tame', antinomies that overlook the numerous entanglements and multi-directional relationalities that sustain our planet's intersecting ecologies and life-systems. Posthumanism thus emerges as an analytical position, a non-anthropocentric ontology that looks at how subjects are formed by forces and dynamics beyond their control (Braun, 2004). Change, in this reading, is an opportunity to look at new forms of becoming and more sophisticated relational arrangements, advancing the idea that the human is not, at any given time, solely human (Agamben, 2004).

Based on these premises, in this article we look at how the impending catastrophe can be productively reimagined from a posthumanist perspective. To do so, we turn to science and climate fiction, and specifically to graphic narratives set in apocalyptic worlds. As Braidotti (2006) and Braun (2015) suggest, such traditionally marginal kinds of popular fiction are drawn to the above-mentioned folding of a hypothetical Euclidean space. In so doing, they successfully challenge a humanistic worldview, allowing us to explore the multiple socio-natural relations and transformations that are produced by socio-ecological change, while also antagonising the narratives that associate the Anthropocene with a looming apocalypse. Indeed, a humanist conception of temporality reduces epochal time and geological eras into timescales - be they linear or atomised - that are easily elaborated through human perception, and this is because they are based on human time and its inherent assumptions on intergenerational inheritance. Under this reading, the end of a world habitable for humans becomes a spectacular end of the world in absolute terms, while we know that this is not necessarily true for the entanglements of beings and entities that inhabit our planet. The temporality of these heterogenous forms of becoming, Braidotti (2005) explains, 'is always the future anterior, that is to say a linkage across present and past in the act of constructing and actualising possible futures'.

Echoing Anderson's (2014: 5) call to 'break out [of] a narrow and humanist conception of culture' and to decentre the human in human geography, this article critically challenges a fundamentally humanist conception of nature, temporality and narrative to examine the agency of the non-human. To support this argument, we show then how popular culture in general, and comics in particular, are pioneering the development of this critical posthumanist perspective, emerging as a productive site through which geographers might interrogate and develop posthuman methodologies and narratives. Through this, we seek to move beyond the nature-society divide that is rendered anachronistic by the Anthropocene. Against this backdrop, assemblage thinking allows us to illustrate the multiple and new flows and connections among things, people and places that emerge in, and are produced by, our understanding of environmental change and degradation. We begin by discussing how geographers and social scientists have looked at posthumanism and assemblage thinking, before outlining the narrative challenges raised by the Anthropocene and the analytical insights offered by graphic 
narratives. We then develop our analysis around Here (McGuire, 2014) and Mad Max: Fury Road (Miller et al., 2015), and conclude with a discussion of our findings.

\section{Posthumanism, fiction and the Anthropocene}

As Castree and Nash (2006) explain, posthumanism signals an analytical and political perspective rather than a historical moment, even though this new perspective arises from new historical conditions such as the rise of technoscience or, we might add, the Anthropocene. Under this lens, much research in geography and the social sciences has abandoned the central focus on humans to explore the emergence of new forms of relationality and subjectivity. Haraway $(2003,2006)$ has made crucial contributions to posthumanist debates through her concept of the cyborg, a hybrid being that epitomises the enmeshing of humans, animals, machines, technologies and other non-humans. As Braidotti (2006: 200) efficaciously observes, the cyborg 'is a connection-making entity; a figure of interrelationality, receptivity and global communication that deliberately blurs categorical distinctions'. This hybrid is reminiscent of what Latour (1993) famously called a 'quasi-object' - that is, objects that are fundamentally social, acquiring meaning and shaping human practice through an entangled set of relations. In the same vein, Whatmore (2002) advances the term 'more-than human' (preferring this to 'posthuman') geographies to shed light on 'what exceeds rather than what comes after the human' (Whatmore, 2004: 1361). Meanwhile, Agamben (2004: 27) suggests that we should understand homo sapiens not as a species but as a fundamentally anthropological (or anthropogenic) machine that produces and recognises the human through the opposition man-animal or humaninhuman - as he argues, the human 'must recognize himself in a non-man in order to be human'. Which is to say, the attributes of the human and the inhuman are themselves unexamined anthropogenic constructions, and it is here that humanism's potentially dangerous and exclusionary authoritarianism comes into view (see also Badmington, 2004).

Going beyond common assumptions about the immutable historical dominance of humans, scholars have investigated the emergence of new relations with a focus on materiality, affect, emotions and enthusiasm (refer for instance to Wolfe, 2010; Roelvink and Zolkos, 2011; Geoghegan, 2013), theorising the human as 'a process made through many more-than-human flows' (Ginn, 2016: 2). If we are to understand these socionatural hybrids, as Swyngedouw (1999) argues, we should not focus on the hybrid as such, but rather on how this hybridization is produced by historical and geographical processes and dynamic choreographies of power. This refusal of traditional hierarchical schemes, and a refocusing of analytical attention upon the concept of becoming, points to a rematerialization of geography and an uptake of assemblage thinking in the discipline (Robbins and Marks, 2010; Dewsbury, 2011). Deleuzian assemblages can be defined as a 'multiplicity which is made up of many heterogeneous terms and which establishes liaisons, relations between them across ages, sexes and 
reigns - different natures. [...] It is never filiations which are important but alliances, alloys; these are not successions, lines of descent, but contagions, epidemics, the wind' (Deleuze and Parnet, 1987: 69). As Delanda (2016) notes, this definition is underpinned by two assumptions: i) that the parts forming an assemblage are not uniform; and ii) that these parts are linked by temporary relations of exteriority. This eradicates notions of intrinsic identity (such as being a father or a daughter), instead insisting on their materialisation through external relations (a father is produced by his relation with his daughter and vice versa). Rather than being fixed or stable, human subjectivity is produced by a multiplicity of relations and encounters that take place in the immanent world (Boundas, 1993). Deleuze (1994) primarily advocates for an ontology of difference which manifests itself through processes of becoming. The subject, therefore, emerges from these processes or habits, as '[w]e are habits, nothing but habits - the habit of saying "I"'(Deleuze, 1991: x). Assemblage thinking places the focus on ephemeral relations of becoming and unbecoming: as Deleuze and Guattari (2004) explain in one of their most provocative examples, the wasp becomes the orchid and the orchid becomes the wasp, their desire-driven encounter producing new forms of being in a mutual process of becoming.

Such a perspective raises important questions in regard to the purposes of this study. For instance, what new forms of becoming (different) are produced by our shifting ecological and political condition? What kind of relations emerge in the apocalyptic scenarios that we are so prone to imagine in the Anthropocene? And finally, the central question motivating this article: what kind of cultural forms might allow us to give narrative shape to the complex temporalities and spatial relations both of the posthuman and anthropocenic epoch?

The novelist Amitav Ghosh (2016) lays out in his book-length study, The Great Derangement, an influential argument: that the Anthropocene defies the linear narrative conventions of literary fiction. Surveying the pages of 'serious literary journals' and book reviews from publications such as the London Review of Books and the New York Review of Books, he finds a worrying dearth of novels tackling issues of climate crisis. For Ghosh, this is much more than market fad or cultural trend; the absence of 'serious', literary climate novels (as opposed to science-fiction (Sci-Fi) or climate-fiction (Cli-Fi) novels, to which we will return in a moment) registers a deep mismatch between the geological time scales of the Anthropocene and the 'human' temporalities of the form of literary narrative fiction. The phenomena of 'climate breakdown' (Monbiot, 2017) - not to mention the violent ruptures of climate instability that increasingly index the era of the Anthropocene - functions to break down the novelistic imagination and its teleological narrative form. Or to put this another way: literary narrative itself breaks down when confronted with subject matter that operates so far beyond and above the human scales of domesticity and everyday life that have, since Jane Austen, been the novel's raison d être (see Moretti, 2006). The anti-exceptionalist bildungsroman ideologies of mundanity and steady progress - with their roots in nineteenth-century geological accounts of the Holocene period and evolutionary theories of human development (Gould, 1988; Smailbegović, 2015) 
- are embedded in and perpetuated by the novel form. For Ghosh, the formal shape of literary fiction is thus consequently unable to narrate, or even to account for, the motions and consequences of human-induced climate change.

Worried by this narrative crisis, Ghosh explores how the novel emerged from and then reified the Enlightenment commitment to dualistic Cartesian rationality: that partitioning (Latour, 1993) of human from non-human (the latter including indigenous populations across the globe). If this partitioning was integral to the colonialist taming of nature through resource extraction and slavelabour exploitation (Goméz-Barris, 2017; Yusoff, 2018), it also enabled the rise to hegemony of an imperial visuality that violently demarcated the surface of the planet into discrete, propertied territories (Mirzoeff, 2011). The novel is the 'aesthetisation' of that which has been classified and separated by this hegemonic visuality. Not only does this aestheticisation lend authority to the regime of visuality; it now repeats it in the era of the Anthropocene. As Mirzoeff (2014: 222-223) offers by way of example, the novels of Charles Dickens and other nineteenth-century novelists aestheticise the oppressive smog of Victorian London, transforming 'a dangerous by-product [...] into a sign of human superiority and the continuing conquest of nature' - it is in this sense that the novel 'anaestheticises' the violence of the Anthropocene through the aesthetic qualities of its form.

It is of course ironic that the conditions that gave rise to this progressive novelistic form were, like Dickens's London, saturated in surging carbon emissions, the effects of which are coming now to disprove Enlightenment narratives of progress. Thus in the twenty-first century, the confident march of novelistic teleology is fragmented by the unruly and violent phenomena of anthropogenic climate change. The novel's Euclidean narrative geometry - which begins at Point A and moves along a smooth line or, at most, a roundabout curve, toward a concluding Point B - is not simply folded by the violence of climate breakdown; it is bent to breaking point. Linear narrative cannot account for the multi-scalar temporalities of the Anthropocene where, having altered the climate at the scale of geological time, humanity's past actions have already caused future disasters about which we, in the present, are able to do very little. As several commentators have observed, we need now to think in "the future perfect tense" (Klein, 2013: 83) if we are to embark upon the kinds of "prospective archaeology" (Mertens and Craps, 2018: 135) that might make narrative sense of the Anthropocene.

The coterminous qualities, or simultaneity, of these multiple temporalities are superbly expressed in the name of the activist group, 'Extinction Rebellion', who occupied public spaces and disrupted key transport infrastructures in London in the spring of 2019. The name evokes an extinction that, though it will occur in the future, has - at least in part - already been caused by humanity's actions in the past. We might therefore say that, as far as geological time is concerned, this mass extinction has already happened; it just hasn't happened yet. This is certainly the case for many non-human lifeforms, even if it is not yet irreversibly true for human ones. With this in mind, Extinction 
Rebellion might therefore be said to be rebelling against the future. Prior to our self-conscious awareness of the Anthropocene era, when it was assumed that humans operated only as biological agents and not as geological ones, such a formulation would not make sense: how can you rebel against the future? You can rebel for the future, certainly, but you would do so by rebelling against oppressive structures in the present, and perhaps by resisting certain historical narratives of the past. But now that future extinctions are encrusted into geological time frames that will shape the earth's climate perhaps for millennia, to rebel against extractivist practices and carbon economies in the present is to also to rebel against the future - not simply for it.

Climate breakdown is such a game-changer, then, because it demands that we develop imaginative vocabularies and narrative systems able to navigate not what are a colossal expansion of timescales (a task with which Victorian novelists such as Dickens were overwhelmingly preoccupied), but what are rather a collapsing of timescales. As Dipesh Chakrabarty (2009: 221) points out, there is something wholly paradoxical about the fact that although we humans do "not experience ourselves as a geological agent", we nevertheless "appear to have become one at the level of the species" (see also Morton, 2013). Geological and human time here come crashing into one another, opening each other up to newly elastic and simultaneous temporal scales - they seize "daily equations of moral and political accounting and drop into them both a zero and an infinity" (Clark, 2012: 150). If the novel form is ill-equipped to conceive of the anthropogenic melding of human into geological time and (with climate breakdown) back again, what sort of cultural forms might be able to withstand this temporal elastication? If, as many commentators have pointed out (Haraway, 2016; Monbiot, 2017; Mertens and Craps, 2018), the question of narrative and storytelling is imperative for political and social mobilisation around the issue of climate change, what posthuman cultural forms are able to reveal to us this imbrication of human into geological timeframes? What narrative systems, moreover, can trace, visualise, diagnose and perhaps even think beyond the 'slow violence' (Nixon, 2011) that the Anthropocene often unevenly - but always impactfully - has already started to enact? And more particularly, if Rob Nixon (2011: 6), in his coinage of that phrase, worries about the tendency of visual culture toward 'spectacle-driven' images that are unable to attend to the 'calamities that patiently dispense their devastation while remaining outside our flickering attention spans', does this mean that we need to dismiss visual forms entirely?

Despite the frequent citation of Ghosh's argument, his assessment is predicated on some consequential occlusions that many critics have already sought to read beyond. Most notable, of course, is his preoccupation with what he readily calls 'serious fiction' (2016: 24), an analytical bias that obscures the narrative possibilities that have long been opened up by the posthuman worlds of science and speculative fictions, as well as in novels by Indigenous authors such as Alexis Wright, Keri Hulme or Witi Ihimaera, or those of 'magical realist' writers such as Ben Okri and even Ghosh himself (see Holgate, 2019). Moreover, many political geographers have explored how examinations 
of representations of the apocalypse in literary and popular culture might provide important insight into contemporary political and policy-relevant issues (Kennedy and Lukinbeal, 1997; Lukinbeal and Zimmermann, 2006; Dodds, 2008; Dittmer and Gray, 2010; Williams, 2011; Yusoff and Gabrys, 2011; Bettini, 2013; Schlosser, 2015; Ginn, 2015; Gergan et al., 2018), and some of this work has even attended to texts that fall into what Ghosh might think of as 'serious' literary fiction. For example, Boykoff and Osnes (2019) have explored how comedy and humor can generate new ways of thinking and taking action about anthropogenic climate change, while Strauss (2015) turns to the novels of Margaret Atwood and Barbara Kingsolver to argue that both utopian and dystopian narratives of socioecological transformation are able to challenge current political imaginaries of climate change. In perhaps the most overt disavowal of Ghosh's contention, in their introduction to a recent special issue of Studies in the Novel, Stef Craps and Rick Crownshaw (2018: 2) have pointed not only to 'seminal recent work that has valorized the popular genres of science fiction and horror, and by extension, weird and speculative fiction', but also to what they call the 'rising tide of climate change fiction' more generally. Indeed, perhaps the best argument against Ghosh's contention is his own work, which beginning with The Hungry Tide (2004) and culminating in his latest novel, Gun Island (2019), has sought to accommodate the newly expansive temporalities of the anthropocene into what he (and others) certainly thinks of as his own 'serious' fiction (see Clark 2019).

There does, however, remain an important point to Ghosh's limited purview of the 'serious', and though he never quite phrases the question exactly, the concern undergirding his contention might be framed thus: why have novels incorporating science fictional and speculative elements been 'banished', at least until recently, from the realm of 'serious' fiction? Adam Trexler, writing in his book-length study, Anthropocene Fictions, has a succinct and revealing answer to this question: the presumed limitations, Trexler writes (2015: 13), of what counts as 'serious' literary fiction arises from an anthropocentric form of literary and cultural criticism - criticism that, like the canonised novels it discusses, proceeds on 'a model of imagination whereby the author pulls all the strings, and character is the center of the fiction. In short, it revolves around the human'. The problem is not only one of content, then, or even form, but also analysis, the 'banishment' of certain SF genres (not to mention 'low' cultural forms) from the realm of the 'serious' itself a consequence of a resolutely humanist and enduringly human-centred mode of literary and cultural criticism that resists more recent shifts to posthuman methodologies.

We therefore want to triangulate, especially in our second close reading of Mad Max: Fury Road, Ghosh's horizontal discussion of the limitations of literary form with the vertical categorisations of genre - even as, we should also add, those categorisations are themselves increasingly challenged by the impact of the anthropocene on narrative form. As Trexler continues (2015: 14), the demands made by climate change on linear narrative 'threaten to rupture the defining features of genre: literary novels bleed into science fiction; suspense novels have surprising elements of realism; realist 
depictions of everyday life involuntarily become biting satire'. If the evergrowing field now known as climate fiction, or 'Cli-Fi' - which invariably collapses the linear temporal scales of past, present, and future - challenges convential scholarly discourse by defying, blending, and borrowing from multiple elements of existing forms and genres (Goodbody and Johns-Putra, 2018), then the renewed interest in posthuman narrative systems - that we are here attempting, and for which we are advocating must surely take account of this work.

\section{The posthuman qualities of graphic novels}

Since the beginning of its gradual rise (c.1980s), the graphic novel has persistently confounded the conventional generic and formal boundaries both of literary and cultural analysis (Baetens and Frey, 2015). What is more, while Ghosh's 'serious fiction' is predicated on smoothing disruptive temporalities out of its linear narrative arc, the graphic novel - or more succinctly, comics - is conversely a form that is predicated on making visible exactly this narrative scaffolding. In so doing, in this section we want to explore the ways in which comics incorporate a more complex engagement with narrative time into their formal composition, producing in turn a spatial layout that maps analogously and productively onto posthuman methodologies.

Scholars of comics studies (Eisner, 1985; McCloud, 1993; Groensteen, 2007) have long pointed out that even the most basic of comic strips reveal to the reader the underlying 'grid' of their narrative composition. For Chute (2016: 4), comics are assembled from a "spatial grammar" that is "suggestive of architecture", while for Davies (2019: 6), graphic narrative can be said to rely on and reveal a narrative "infrastructure of grids, gutters and panels". This spatial-sequential layout can be thought of as an "infrastructural form" (Davies, 2019: 17), a visual-narrative assemblage that allows comics to "strip back the construction process both of [their] narrative" and the various environments they represent (11-12). Thus in their very structure, comics reveal "that which cannot be reconciled to linear narrative - the excess that refuses cause-and-effect argument, the trace that threatens to unsettle the present's narrative of its own past (and thereby of itself)" (Gardner, 2006: 801).

Graphic narrative is so-called because, rather obviously, it builds its narratives from the sequential organisation of multiple graphics. However, the label contains another meaning as well: because comics' infrastructural form is predicated on making the joins and seams of narrative visible to readers, comics might also be said to be graphic about the process of their narrative composition. Their basic infrastructure of grids, panels, frames and gutters index graphically, on the very surface of the page, the processes by which narrative is constructed - such as the selective inclusion and occlusion of different temporal moments, and the invitation to readers to draw cause-and-effect relations between them. Importantly, we want to argue here, this graphic representation of narrative infrastructure has a tendency toward the posthuman. For if, as Bruce Clarke observes (2008: 13), narrative has always been "a primary formal and thematic program running on the complex 
infrastructures of social and psychic systems", it is only recently, with the posthuman turn and in the era of the Anthropocene, that we have "noticed that systems are inexorably coupled to the environments they distinguish themselves from". Though not focusing specifically on comics, Clarke (2008: 47) identifies the inclusion of "self-referential structures" and the construction of "narratives of narrative" - which accurately describes the infrastructural form of graphic narrative - as central to the posthuman metamorphosis of narrative systems.

Revealing on the surface of the page multiple events simultaneously as well as sequentially, comics expose their narrative infrastructure not only as some meta-visual, self-reflexive strategy (though they do often deploy it to this end), but as a fundamental component of their formal composition. As McCloud (1993: 7) has influentially remarked in his comparison of graphic narrative with the temporal constraints of film, comics represent time not temporally but spatially; that is, they represent time as space: "Each successive frame of a movie is projected on exactly the same space - the screen - while each frame of comics must occupy a different space. Space does for comics what time does for film”. Developing McCloud's observation further, Groensteen (2007: 6) reads comics as a system that depends on "the simultaneous mobilisation of the entirety of codes (visual and discursive) that constitute it". Time is held spatially on the page(s) of the comic, inviting readers to think beyond the linear confines of conventional filmic or novelistic forms and instead to read for the assemblage of relations that connect multiple temporal moments together, both spatially and simultaneously (see del Rey Cabero, 2019).

For Jason Dittmer (2014: 478), comics thus function as "narrative assemblages" that resist "static and anthropocentric" readings of environmental systems (Dittmer, 2014: 478). As King and Page (2017: 7) also point out in their important book, Posthumanism and the Graphic Novel, narrative forms such as comics are "impossible to analyse as an autonomous, 'unified' and dematerialized entity in the humanist manner"; they cultivate in readers (and geographers and critics) posthuman ways of looking. Comics might be said to introduce what Mirzoeff (2014: 228-229) calls a 'countervisuality', which by his definition moves not in "a linear, tactile fashion", but rather through moments of rupture that render "resonance with similar moments in the past suddenly [...] perceptible". In comics this countervisual movement occurs not only conceptually or metaphorically, but formally, on the surface of the page. Describing "comic book visualities", Dittmer (2010: 223, 235) dissects the form to show how it produces narrative simultaneity, polyphony and "plurivectoral reading practices", which move against and around the linear monotony of the "mechanised and standardised temporality of filmic" and we might add, novelistic - projection. Or as Jeffrey (2016: 4) argues in his Deleuzian reading of superhero comics, graphic narrative can be said to operate rhizomatically, resisting chronological causality in and through its formal composition to instead present "history and culture as a map of influences and events with no specific cause". Following King and Page (2017), we would go so far as to venture that comics might, in some instances at least, be considered a form with posthuman 
tendencies - by which we mean that there are provocative analogies between posthuman narratives and methodologies and the formal shape of the comics page(s). Comics worlds are of course filled with the posthumanism of popular culture and genres such as SF, with their superheroes and alien humanoids and transmedial narrative connections. But they are also critically posthumanist, often interrogating - as the examples we analyse below demonstrate - through the peculiar temporalities of their formal composition "the ways in which agency and the production of knowledge have always been the emergent product of a distributed network of human and non-human agents" (King and Page, 2017: 3).

It is the assemblage-like, posthuman tendencies of the comic's form (though he does not describe them as such) that lead Ghosh (2016: 84) himself to point out the historical alignment of the rise of the graphic novel - from the late twentieth-century into the twenty-first - and the development of humanity's self-consciousness of the Anthropocene epoch. There are of course far too many other factors - from the rise of television, advertising, and the internet (Gardner, 2006: 802-803), to the mainstreaming of trauma discourses (Chute, 2010) and the mediafication of war (Chute, 2016) - to suggest such a direct relationship. Nevertheless, on the one hand, it is exactly their adverse - some have argued even antidotal (Mickwitz, 2016) - relationship with a spectacle-driven visual culture that suggests comics might better capture the 'slow violence' of the Anthropocene that Nixon (2011: 6) worries is so absent from contemporary 'corporate media'. On the other, and as we have shown above, a number of critics are increasingly coming round to the idea that graphic narrative might be an especially "fruitful site for investigating the capacity of both visual art and literature to respond to [the current] refiguring of the boundaries of the human subject and narrative" (Perry, 2018). Building on theses shift, we want to show here how the infrastructural forms and rhizomatic assemblages of comics have the capacity to throw a critical posthumanist perspective into relief, and in so doing to narrate the kinds of elastic, anti-linear temporalities of the Anthropocene. It is this ability to build new narrative structures that entwine the non-human with the human, and to radically challenge the linear, Enlightenment-conception of time as a march of teleological progress, that allows us not only to think of comics as a for with particular posthuman tendencies and capabilities. More than this, we can think with comics in order to develop new posthuman methodologies capable of visualising the multi-scalar temporalities of anthropogenic climate systems, as the following discussion of Here and Mad Max: Fury Road will now demonstrate.

\section{The atemporalities of Here}

Perry (2018) identifies Richard McGuire's 2014 graphic novel Here as an especially instructive example of the ways in which comics are able to enmesh human and geological temporalities visually on the page. While Mad Max: Fury Road has an anti-linear narrative, Here functions as a formal thought experiment that dismembers even the conventional infrastructure of the graphic novel. McGuire eschews chronological sequentiality almost entirely, seeking instead to replace it with a 
visuality of temporal simultaneity. As the celebrated cartoonist Chris Ware (2014) observes, "McGuire places the reader into the space of the story for a journey through all of time, from the earliest days on Earth past the time when humanity will no longer exist”.

Here is comprised of over three hundred double-page spreads that all depict the same "space" - the place of McGuire's childhoood home in North America - at different moments in history. Small text boxes with dates are included in the corner to situate each of these spreads in a specific moment in time. These dates range from the year 500,957,406,073 BCE (shown as nothing more than a radioactive mass of ephemerous gasses), to our own moment at the turn of the twenty-first century (which plays out in the domestic living space of a single home, a scale to which the novel form is accustomed), and then beyond into the future as far forward as the year 22,175 CE (where a bright pink flower and a peculiar elephantine creature indicate an ecologically rejuvenated, now non-human world). However, and crucially, the pages do not proceed chronologically, but rather jump disorientatingly back and forth across millennia, while the title - Here - insists on the felt immediacy of, and implicit connections between, both distant past and projected future as they impact upon the present. If McGuire's decision not to include page numbers means that we are unable to point to the exact moments where various scenes occur in the narrative, this only serves to reinforce Here's resistance to the linear sequentiality of the novel form.

By scattering images of daily life from the 1970s through to the 2000s in and amongst much larger geological timeframes, McGuire demonstrates how comics are able to insert human narratives into a much larger assemblage of non-human systems. On the majority of pages multiple timeframes are depicted simultaneously: panels from previous and forthcoming pages appear pasted over the background of the present of any specific page. These smaller inset panels in turn contain micronarratives - or story fragments - that, though grounded in novelistic narrative time, gesture knowingly (and sometimes satirically) to the Anthropocene's rupturing of human timescales. Consider, for example, an early sequence, in which four aging adults from 1989 are shown sitting in a living room sharing a joke. 'A guy calls a doctor for some test results', the first panel tells us, while the present of the page behind this domestic scene is labelled 8,000 BCE and shows only abstract swampy marshland. Turning overleaf, the joke continues - the doctor has 'some good news and some bad news' - meanwhile the present of the page now moves forward to 1,009 BCE, again depicting only an abstract image of leafy greenery. 'The good news is you have twenty-four hours to live', says the doctor - the present of the page now shifts to 1573 and shows a small river running through a snowy forest. Turning the page again, the joke concludes: 'That's the good news?! What's the bad news?' The bad news, says the doctor, is that 'I should have told you yesterday'. 
Insert Fig.1: The micronarrative of a joke delivered in 1989 is superimposed over settler colonialists building a house somewhere in North America in 1764.

With this sense of foreboding - the joke after all capitalises on a sense of lost time, evoking the anthropocegenic intrusion of the future into the present - the page now shifts to 1764 , where silhouetted figures are shown building an early colonial mansion (see Fig.1). Situating itself at the onset of our self-consciousness of the Anthropocene era (1989), and politicising the global inequalities embedded in the Anthropocene from its inception by referencing eighteenth-century colonial expansion (Lewis and Maslin, 2015), the architectural scaffolding of this early colonial mansion here shadows the infrastructural form of the comic itself. While the fluorescent red colours of this page imbue settler colonialism in the Americas with an atmosphere of environmental toxicity, this micronarrative sequence in turn concludes with the sudden death of one of the older adults listening to the joke. As soon as the punchline is delivered, this adult begins to cough, eventually toppling over backwards on his chair. Meanwhile his companions continue to laugh around him, preoccupied by the micronarrative of the joke and thus remaining mostly oblivious to his - and implicitly humanity's - oncoming extinction.

As this man coughs, the present of the scene behind him moves forward from 1764 to 1783 , where the now completed colonial mansion billows out red smoke - smoke that is, of course, aesthetically suggestive of surging carbon emissions. But this aesthetic representation is not an anaesthetic one. Rather, by embedding the sequential micronarrative of the joke within these much larger temporal shifts, McGuire invites us to draw rhizomatic connections - as opposed to simple linear, cause-andeffect relations - between geological and human timeframes: the carbon emissions fuelling colonial settlement at the end of the eighteenth century here seem to seep into the 1980s where they quite literally choke a man to death. Here, it is specifically the rhizomatic formal infrastructure of comics allow McGuire to insist on the simultaneous co-existence of these multiple temporal scales.

If the scaffolding of the colonial mansion is smuggled into Here as an in-textual reference to comics' formal infrastructure, McGuire makes another structural reference to his formal techniques when he first allows us a glimpse into the comic's speculative future. Arriving abruptly in 2050, McGuire draws two (significantly ageing) characters playing a hologrammic boardgame that is comprised of multiple squares hanging vertically in the air. The form of the boardgame strikingly resembles McGuire's own double-page spreads, with their rectangular, double-page backdrops and their overlays of internal floating panels. By introducing the comic's infrastructural shape as a visual motif within the narrative itself, McGuire suggests the very process of meaning-making in the Anthropocene era as a kind of game. After all, throughout Here, the comic's narrative infrastructure invites us to draw connections between what are otherwise distant temporal timeframes. Even though many of these frames are so distant that relations between them seem absurd, we "still look for 
closure and try to connect the frames" (Mertens and Craps, 2018: 140), playing a narrative game one that, in the end, resists completion.

McGuire thus instils in his readers an awareness that it is they who are responsible for drawing connections between the comic's discrete narrative segments. We find ourselves compelled to seek even though we mostly fail - to build a sequential narrative out of the dislocated temporal moments presented to us. While Here evokes an anthropogenic narrative that entwines human and geological timescales, it therefore also warns readers against anthropocentric reading processes (Caracciolo, 2016). The complex assemblage of coterminous yet distant temporal frames highlights the risk of reinserting an anthropocentric perspective - in which "Western-indebted people [...] figure themselves as individuals and societies of individuals in human-only histories" (Haraway, 2016: 3031 ) - into the transformative period of the Anthropocene. For as we read and attempt to make sense of the comic, we are forced to reflect critically on our own compulsive attempts to reconstruct a causeand-effect narrative sequence, and in so doing, to re-centre the human into the disorientation of McGuire's posthuman world.

Insert Fig.2: Here's busiest page contains multiple panels from different historical moments.

The formal shape of the boardgame from 2050 is most obviously reiterated in what is Here's busiest page (see Fig.2). Here, multiple panels from different historical moments from the 1950s through to the 1980s show domestic items breaking - plates, wine glasses, mirrors - as if in an earthquake, while similar speech balloons capture disembodied exclamations and insults - 'jerk', 'klutz', 'shithead', 'geek' - all at the same time. The multiple panels on this page defy linear sequence, as readers are required to read across several moments of rupture that are shown to occur simultaneously. Doublingdown on the posthuman qualities of the page's narrative structure, no humans are visible in this scene; geological time, manifesting as an earthquake, has literally shaken them out of the frame. As Rodriguez (2018: 379) observes of this page, "what could possibly be abstract ecological disaster is, actually, on the same embedded scale of all of these other framed intentional acts of insult or breakage".

It is significant, then, that McGuire also uses this page to introduce an impending, and eventually actualised, apocalyptic flood. In the page's largest inset panel - dated 2111 - he draws a large tidal wave of water breaking through the glass of the window of the domestic (for which we should by now read human) space-time. While the frame of the windowpane self-referentially reminds readers of the narrative infrastructure of the comic's panels, the water that floods into the room visualises in this moment of rupture the intrusion of geological into human timeframes. The linguistic echoes between timeframes and comics frames are not lost on McGuire, who instead exploits this synergy to evoke an 
atmosphere of "impending calamity, [of] being 'out of time"" (Perry, 2018). And indeed, we are out of time: later in the comic we find that, just two years later, in the year 2113, the space of the present is now entirely under water, the flood having swept away all traces of twentieth- and twenty-firstcentury human life (see Fig.3).

Insert Fig.3: A flood in 2113 has swept away domestic space, which is now entirely under water.

Yet there remains on this apocalyptic page two human figures shown in hanging panel insets, from 1962 and 1994 respectively. Significantly, both of these humans have 'lost' something - an elderly woman is losing her hearing, while a young woman has lost an earring, a lyrical echo that one of the comic's anonymous characters later calls 'the oddity of rhyming events' (see Rodriguez, 2018: 366). In the rhyming echo of hearing and earring, it seems at first as though the two women are speaking to each other across the page. The page's layout, which will be followed by Western readers from lefthand to righthand panels, invites us to superimpose a cause-and-effect logic onto these frames. This tantalising chronology suggests that the young woman from 1994 has misheard the older woman from 1962. But though the narrative infrastructure invites this sequential reading, the dates of these panels reject it; humans cannot after all communicate verbally across thirty-year periods. Depicting both women in a moment of mis-(h)earing, the failed communication between them instead suggests the breakdown of human-centred narrative systems. Both characters have quite literally 'lost time'; the rest of the page, after all, is entirely under water, visualising an instance of climate breakdown that quite literally breaks down the cause-and-effect sequencing of linear narrative.

In an effort to make sense of the narrative 'system' of the shorter, six-page predecessor to the later and longer graphic novel, which McGuire also entitled 'Here' (1989), Groensteen (1991) claims to have photocopied each page of the comic and reassembled it into chronological order, from $500,957,406,073 \mathrm{BCE}$ to $2033 \mathrm{CE}$ (this shorter comic did not go as far into the future as 22,175 CE) only to find that "all of the sequential action that could be construed as a conventional narrative is exceedingly banal" (Moncion, 2017: 204). Human narratives are rendered inconsequential in Here, extricated from the comic's anthropogenic temporal assemblages through the erosion of their sequential significance. The infrastructural form of comics allows McGuire to construct a posthuman narrative system, one that conjures the anthropogenic temporalities that have rendered Enlightenment humanism and its attendent narrative forms (manifested most obviously in Ghosh's 'serious' novel) banal, if not obsolete.

And yet the speculative currents of McGuire's comic - currents that are after all literalised in the apocalyptic heft of the flood water as it crashes through the comic's narrative (window) frame remain just that: speculative. If the narrative form of the novel is therefore not quite yet obsolete, at 
least in the present of our reading of the comic, its banality contains a further reflection. In her reading of Hannah Arendt's (1994) reflections on Adolf Eichmann, Haraway (2016: 36) refigures the banality of Eichmann's evil as the evil of Enlightenment humanism: "Here was someone who could not be a wayfarer, could not entangle, could not track the lines of living and dying, could not cultivate response-ability, could not make present to itself what it is doing, could not live in consequences or with consequence, could not compost." While not suggesting that its human readers are as 'evil' as Eichmann, Here does imply that the banality of its domestic scenes - predicated as they are on a voracious carbon economy and its violent geological consequences - are embedded in an environmental 'evil' that extend beyond the realm of the human. By shifting visually outside of this realm to entangle these banal scenes within larger ecological webs and posthuman systems, Here demands from its readers a 'response-ability', to use Haraway's phrase. Having made us graphically aware of the infrastructure of our narrative systems, Here posits an invitation to readers to rebuild them, this time with the posthuman fundamentally in mind.

\section{Apocalyptic fictions and Mad Max: Fury Road}

Gergan et al. (2018) rightly warn against the tendency of apocalyptic narratives to "offer parallel imaginings of apocalypse that escape specific culpability (for instance, in processes of settler colonialism, capitalism, or imperialism)" (2018: 2). As they continue, their "deferral of disaster to the future" - and, we should add, the past - erases "the ways in which climate change already affects livelihoods (differentially)" in the present (2018: 8). What is needed - and is increasingly being realised - is a Sci-Fi genre that defies the distancing "white affect" of the Hollywood apocalypse, while insisting on speculative fiction as a productive pool from which to draw "new models of collective organization to address global emissions and local impacts" (Trexler, 2015: 25). As we have been insisting throughout this article, the critical perspective of posthumanism, and the narrative assemblages offered in forms such as comics, might enable us to "preserve the urgency of the Anthropocene without re-deploying destructive understandings of humans/nonhumans" (Gergan et al., 2018: 11).

Combining Sci-Fi's cross-genre "patterning of possible worlds and possible times" (Haraway, 2016: 31) with the posthuman qualities of the comics form, we therefore continue our empirical analyses with a reading of Mad Max: Fury Road (Miller et al., 2015) - not the film, but the subsequent comic, which positions itself as a "prelude" to the film's events. The 2015 blockbuster has been widely celebrated for its critiques of water scarcity - by NASA's chief water expert Jay Famigletti, no less (Onal, 2015); for its opposition to "normative understandings of the body by making characters with disability central to its narrative" (Fletcher and Primack, 2017: 345); and for its critique of automobility, ecomobility and the commodification of natural resources (Pesse, 2019). For our concerns, it is worth highlighting that the narrative world of the film, Mad Max: Fury Road, is able to tell two stories - which often do not sit comfortably with one another - at the same time: on the one 
hand, its post-apocalyptic scenario offers a collective story of (post)human solidarity in the face of the threat of the Anthropocene; and on the other, it critiques the endemic inequalities and uneven life chances that the Anthropocene throws up. To repurpose Rob Nixon's (2014) words, the characters of Mad Max: Fury Road "may all be in the Anthropocene, but [they're] not all in it in the same way".

Reading comics against filmic forms, Dittmer (2010: 232-233) emphasises the ways in which graphic narrative is able, unlike film, to "hold time still", or to "accelerate or stop within and between panels". As he continues: in comics, formal infrastructures such as " $[\mathrm{m}]$ ontage and the gutter provide disruption and reconfiguration of meaning through their radical Openness; they literally create geographical space for the reader to produce their own narrative". Perhaps unsurprisingly, then, the comic book version of Mad Max: Fury Road departs fundamentally from the linear narrative infrastructure (the 'fury road') of its filmic namesake. It is set both before and after the events of the film, expanding the central infrastructure of the fury road outwards both temporally and spatially to encompass an assemblage of narrative strands. Which is to say, the comic imitates the simultaneous temporal rhythms of the Anthropocene, collapsing pasts and futures around and into the present of the film - even while the filmic present is itself absent from the comic.

The comic is a prelude to the film in the sense that its discrete narrative segments provide backstories to the film's main characters: Immortan Joe, Nux, Furiosa, and Max. But these strands are held together by a frame narrative, a common enough technique in comics, novels and films alike. This frame narrative introduces and concludes each of the comic's four sections, all of which, like Here, are disorientatingly bereft of chronological page numbers. In this frame narrative, a 'History Man', who is situated in the future, after the events of the film, educates a room of young children about the histories that occurred before them. These are stories, he remarks, "by which to navigate the future... and avoid a repetition of the past" (Miller et al., 2015). While these histories are recorded on small pieces of parchment called "Word Burgers", they are also daubed onto the body of the History Men and History Women themselves (see Fig.4). This History Man's skin is tattooed with disparate chunks of text that a reader must piece together to build new narratives, just as readers of comics must assemble their graphic fragments and thread them through with meaningful relations. Which is to say, these narrative fragments assemble onto the body of the History Man, self-referentially directing our attention to the posthuman qualities of comics' "textual constitution" (King and Page, 2017: 12).

Insert Fig.4: The History Man, tattooed with narrative fragments, stares out at the reader, confronting them with the simultaneous temporalities of the Anthropocene. 
With this narrative frame the comic enters the future perfect tense, as the History Man tells us - that is, us readers in the twenty-first century - what "will have been". The paradox of apocalypse, as Klein points out (2013: 84), is that it is "impossible to represent the end, since representation always follows what it describes": the problem for climate activists is that no one "is competent to speak authoritatively about what can only be viewed from beyond the end". But the comic navigates a route through this tension by creating a character whose own body is inscribed with the posthuman narrative systems required to encompass the Anthropocene's collapsing of Enlightenment temporalities: if the "ultimate catastrophe" must always remain a "fiction", as Klein asserts (2013: 85), then the History Man reminds us that "it nevertheless is one that has very material consequences in the present". The comics makes implicit reference to Walter Benjamin's 'On the Concept of History' here, suggesting both the History Man and the comic itself as a formal materialisation of "the angel of history", for whom linear temporalities of cause and effect collapse in on one another and are seen to occur simultaneously. As Benjamin (2006: 392) writes, where "a chain of events appears before $u s$, [the angel of history] sees one single catastrophe, which keeps piling wreckage upon wreckage"; the illusion of "progress" that linear narrative imposes upon such events is indicatively called, for Benjamin, a "storm".

Insert Fig.5: The 'fury storm' beats down on the infrastructure of the Citadel and the narrative infrastructure of the comic.

It is therefore doubly significant that, in a later scene, the History Man directly invokes Benjamin's language, literalising his metaphor of the storm so that it encompasses the threat of climate crisis. "Behold the fury storm!", he exclaims, pointing to the sandstorm that rages outside: "out there... that's history. Standing between us and the future, warning us to be vigilant - to learn the lessons of the past..." (Miller et al., 2015; see Fig.5). In his description of climate breakdown as 'history', he appears to consign it to the past; and yet the accompanying images, which show the storm beating against the glass of the Citadel, make clear that this history continues to press down violently on the narrative present and to threaten the narrative future: this is "one single catastrophe", as Benjamin might observe. The infrastructure of the steel beams and thick glass that keep the storm at bay here almost bleed into the narrative infrastructure of the comic's panel borders and gutters. It is as though the storm is beating down on the infrastructure of the comic in order to shake the narrative out of chronological order. In this instance of anthropogenic rupture, the page is collapsed into an assemblage of past, present and future, warning us "to learn the lessons of the past... or be swept away". While the History Man is speaking here to the children who listen to his tales, the fact that he is frequently depicted head on, facing out of the page directly at the reader, suggests that he is also 
talking to us (see Fig.4). The result is a refusal to "displace" apocalypse into the future, and to remind us - readers in the West, especially - that in fact this is an apocalypse that has "already happened" (Gergan et al., 2018: 2).

Insert Fig.6: The relatively geometric infrastructure of Mad Max: Fury Road breaks down into a series of fragmented, temporally disparate scenes.

There are clear synergies between apocalyptic narratives and the comics form. As Fuist (2016: 97) observes, Mad Max: Fury Road, the film, "like many postapocalyptic stories, identifies human beings as compulsive producers of culture", suggesting that, "when stripped of our institutions, we rebuild them anew". Comparably, the infrastructural form of graphic narrative invites us to rebuild narrative from the graphic fragments with which we are presented - even while, as David McGuire's Here demonstrates, they can also ask us to reflect critically on the process of narrative construction itself. This shows up in the temporally simultaneous narrative spaces of the comics form, where images of environments and catastrophes insist that we incorporate posthuman systems into our reconstructed narratives. In the comic, Mad Max: Fury Road, this occurs most obviously in the prelude to Max's backstory, where the relatively regular, geometric narrative infrastructure of pages, panels, and gutters, breaks down yet further into a series of double-page assemblages of fragmented, temporally disparate scenes (see Fig.6). These panel fragments return to "a past that started before the fall" implying the present of our own twenty-first-century reading - to show a world "powered by the black fuel" (oil). They then show the process of climate and societal breakdown, a breakdown that is reiterated in the fragmentation of the page's narrative infrastructure. In the page's most revealing panel, climate activists are shown protesting against 'lies' and 'waste', their placards appearing as panels within the panel. The text accompanying this scene is written in an instructive tense - not future present this time, but fully past: "finally, the people awoke from their complacency, realised their peril...". If this action is futile for the future narrative world of the comic, the collision of this future into our own readerly present calls upon us to act - before "it was all too late" (Miller et al., 2015).

Insert Fig.7: A sudden splash page shows the smoky, flaming city of Gastown, bringing the forward movement of the narrative to a jolting halt. 
Indicatively, the temporal disorientation of these double-page assemblages - which do not occur anywhere else in the comic - conclude with a striking splash page that shows the smoky, flaming city of Gastown, emitting toxic carbon emissions into a thunderous sky (see Fig.7). The comic's narrative infrastructure is entirely eradicated here, first dissolving into the page and then re-crystallising as the infrastructure of Gastown's complex of pipes and chimneys. The temporal effect of the splash page is to bring the narrative's forward movement to a sudden stasis, forcing us to confront an apocalyptic image of climate destruction. But as the accompanying text insists, even this momentary vision of an apocalyptic present remains caught within the entangled temporalities of past and future: "the mistakes of the past are repeated over and over... eating away our future... leaving a blighted and polluted world... as its legacy" (Miller et al., 2015). It is the posthuman tendencies of the comics form that allows it to force this vision of anthropogenic apocalypse into our own present, as climate breakdown invades, like the flood of McGuire's Here, the novel's human-centred space with a future history of "human-technological-animal entanglements" (King and Page, 2017: 3).

\section{Conclusions}

Both Here and Mad Max: Fury Road provide powerful illustrations of the posthuman qualities of comics, suggesting graphic narrative as one kind of popular culture among many that can help us to make sense of the ontological drifts enthused by the Anthropocene. These comics invite us to think about the ephemerality of human subjectivity and the multiplicity of atemporal relations, encounters and entanglements behind posthuman forms of becoming and unbecoming, and thus can help us to overcome the demands made by climate change on linear narrative. If so-called 'serious' fiction is failing us, then we should surely pay heed to those 'low' cultural genres and forms that, exactly because of their hybrid natures, have been marked out as "separate from literary fiction" (Ghosh, 2016: 70). Posthuman assemblages, which are made visually possible through the narrative infrastructure of comics, allow us to think about the transformations of the Anthropocene without necessarily reproducing the nature-society divide that has long been the underlying organising assumption of humanist conceptions of nature.

For Haraway, we do not live in apocalyptic times. We do not live in an era of emergencies; or at least, not yet. We inhabit instead one of urgencies, and it is these "times of urgencies that need stories" (2016: 37). In this article, we have followed Haraway and others to take inspiration from, and find new stories in, the imaginative worlds of science and speculative fictions: "SF is storytelling and fact telling; it is the patterning of possible worlds and possible times, material-semiotic worlds, gone, here, and yet to come" (31). If Ghosh is preoccupied by the limitations of literary fiction and the novel form, this preoccupation obscures the narrative possibilities that have long been opened up by the posthuman worlds of science and speculative genres, on the one hand, and the posthuman qualities of popular forms such as comics, on the other. Heeding more attention to the many circulating narratives of the Anthropocene can be instructive for human geography and the social sciences more broadly, 
helping us to understand that posthumanism's decentring of the human does not go against the interests of humans. On the contrary, posthuman thinking enables us to move beyond depoliticising ecologies of fear so that we can think about the 'unthinkable' human catastrophe and realise that the crisis of apocalypse is already happening, right under our nose. It is only by abandoning our tendency to live temporality in a fundamentally subjective way that we can start taking responsibility for the current climate crisis, and perhaps, become more successful in addressing it.

\section{Acknowledgments}

We are grateful to Rosemary Collard and the three anonymous reviewers for their detailed, constructive and insightful comments. We also wish to thank Samir Harb for his generous support and comments on earlier versions of this work, and Annalisa Addis for providing the spark that started the journey of this paper in 2017. This paper is dedicated to the memory of Giaime Loi, a comics artist who did not hesitate to trespass the borders of linear story-telling to challenge his and his readers' feelings and emotions.

\section{References}

Agamben G (2004) The open: Man and animal. Stanford University Press.

Anderson K (2014) Mind over matter? On decentring the human in Human Geography. Cultural Geographies 21(1): 3-18.

Arendt H (1994) Eichmann in Jerusalem: A Report on the Banality of Evil. London: Penguin Books.

Asafu-Adjaye J, Blomquist L, Brand S, Brook BW, DeFries R, Ellis E, Foreman C, Keith D, Lewis M, Lynas M and Nordhaus T (2015) An ecomodernist manifesto. Available at: http://www.ecomodernism.org/ (accessed 4 May 2019).

Badmington N (2004) Mapping posthumanism. Environment and Planning A 36(8): 1344-1351.

Baetens, J and Frey H (2015) The Graphic Novel: An Introduction. Cambridge: Cambridge University Press.

Benjamin, W (2006) Selected Writings, Volume 4, 1938-1940. Howard Eiland and Michael W. Jennings eds. Edmund Jephcott and Others trans. Cambridge, Massachusettes: Harvard University Press.

Bettini G (2013) Climate barbarians at the gate? A critique of apocalyptic narratives on 'climate refugees'. Geoforum 45: 63-72.

Boundas CV (Ed) (1993) The Deleuze Reader. New York: Colombia University Press.

Boykoff M and Osnes B (2019). A Laughing matter? Confronting climate change through humor. Political Geography, 68: 154-163.

Braidotti R (2003) Metamorphoses: Towards a materialist theory of becoming. John Wiley \& Sons. 
Braidotti, R. (2005). Affirming the affirmative: On nomadic affectivity. Rhizomes 11/12.

Braidotti R (2006) Posthuman, all too human: Towards a new process ontology. Theory, culture \& society 23(7-8): 197-208.

Braun B (2004) Querying posthumanisms. Geoforum, 3(35): 269-273.

Braun B (2015) Futures: Imagining Socioecological Transformation-An Introduction. Annals of the Association of American Geographers 105(2): 239-243.

Bruni L (2019). The Economy of Salvation: Ethical and Anthropological Foundations of Market Relations in the First Two Books of the Bible. Springer.

Caracciolo M (2016) 'Qui e allora: Narrazione e temporalità cosmica in Here di Richard McGuire.' In Sara Colaone and Lucia Quaquarelli ed., Bande à part: Graphic novel fumetto e letteratura. Milan: Morellini, pp.177-191.

Castree N and Nash C (2006) Posthuman geographies. Social and Cultural Geography 7(4): 501504.

Chakrabarty D (2009) 'The Climate of History'. Critical Inquiry 35: 197-222.

Chute H (2010) Graphic Women: Life Narrative and Contemporary Comics. New York: Columbia University Press.

Chute H (2016) Disaster Drawn: Visual Witness, Comics, and Documentary Form. Cambridge, MA: The Belknap Press of Harvard University Press.

Clark A (2019) Gun Island by Amitav Ghosh review - climate and culture in crisis. The Guardian, 5 June. Web. https://www.theguardian.com/books/2019/jun/05/gun-island-amitav-ghosh-review. Accessed 9 September 2019.

Clark T (2012) 'Derangements of Scale'. Telemorphosis: Theory in the Era of Climate Change. Tom Cohen ed. Ann Arbor: Open Humanities Press, pp.148-166.

Clarke B (2008) Posthuman Metamorphosis: Narrative and Systems. New York: Fordham University Press.

Craps, S, and Crownshaw, R (2018) Introduction: The Rising Tide of Climate Change Fiction. Studies in the Novel, Vol.50, No.1: 1-8.

Dalby S (2009) Security and environmental change. Polity.

Davies D (2019) Urban Comics: Infrastructure and the Global City in Contemporary Graphic Narratives. Abingdon: Routledge.

Davis M (1999) Ecology of fear: Los Angeles and the imagination of disaster. Vintage Books. del Rey Cabero E (2019) 'Beyond Linearity: Holistic, Multidirectional, Multilinear and Translinear Reading in Comics.' The Comics Grid: Journal of Comics Scholarship 9(1).

DeLanda M (2016) Assemblage theory. Edinburgh University Press.

Deleuze G (1991) Empiricism and Subjectivity: An Essay on Hume's Theory of Human Nature. Trans. Constantin. 
Deleuze G and Guattari F (2004) A Thousand Plateaus: Capitalism and Schizophrenia. Trans. Brian Massumi. London: Continuum.

Deleuze G and Parnet C (1987) Dialogues. New York: Columbia University Press.

Dewsbury JD (2011) The Deleuze-Guattarian assemblage: plastic habits. Area, 43(2): 148-153.

Dittmer J and Gray N (2010) Popular geopolitics 2.0: Towards new methodologies of the everyday. Geography Compass 4(11): 1664-1677.

Dittmer J (2010) Comic book visualities: a methodological manifesto on geography, montage and narration. Transactions of the Institute of British Geographers 35(2): 222-236.

Dittmer J (2014) 'Narrating Urban Assemblages_Chris Ware and Building Stories'. Social \& Cultural Geography 15:5: 477-503.

Dodds K (2008) Hollywood and the Popular Geopolitics of the War on Terror. Third World Quarterly 29(8): 1621-1637.

Eisner W (1985) Comics and Sequential Art. Florida: Poorhouse Press.

Fletcher B and Primack AJ (2017) 'Driving Toward Disability Rhetoric: Narrative, Crip Theory, and Eco-Ability in Mad Max: Fury Road'. Critical Studies in Media Communication 34(4): 344-357.

Fuist TN (2016) 'Religion, Gender, and Power in Mad Max: Fury Road'. Humanity \& Society 40(1): 97-99.

Gardner J (2006) 'Archives, Collectors, and the New Media Work of Comics'. MFS Modern Fiction Studies 52(4): 787-806.

Geoghegan H (2013) Emotional geographies of enthusiasm: belonging to the Telecommunications Heritage Group. Area, 45(1): 40-46.

Gergan M, Smith S and Vasudevan P (2018) Earth beyond repair: Race and apocalypse in collective imagination. Environment and Planning D: Society and Space.

Ghosh A (2016) The Great Derangement: Climate Change and the Unthinkable. London \& Chicago: The University of Chicago Press.

Ginn F (2015) When Horses Won't Eat: Apocalypse and the Anthropocene. Annals of the Association of American Geographers, 105(2): 351-359.

Ginn F (2016) Posthumanism. International Encyclopedia of Geography: People, the Earth, Environment and Technology: People, the Earth, Environment and Technology, 1-9.

Gómez-Barris M (2017) The Extractive Zone: Social Ecologies and Decolonial Perspectives. Durham: Durham University Press.

Goodbody A and Johns-Putra A (eds) (2018) Cli-Fi: A Companion. Oxford: Peter Lang.

Gould SJ (1988) Time's Arrow, Time's Cycle: Myth and Metaphor in the Discovery of Geological Time. Harvard: Harvard University Press.

Groensteen T (1991) 'Les lieux superposés de Richard McGuire’. Urgences 32: 95-109.

Groensteen T (2007) The System of Comics. Bart Beaty and Nick Nguyen trans. Jackson: University Press of Mississippi. 
Grove KJ (2010) Insuring “our common future?” Dangerous climate change and the biopolitics of environmental security. Geopolitics, 15(3): 536-563.

Haraway DJ (2003) The companion species manifesto: Dogs, people, and significant otherness (Vol. 1, pp. 3-17). Chicago: Prickly Paradigm Press.

Haraway DJ (2006) A cyborg manifesto: Science, technology, and socialist-feminism in the late 20th century. In The international handbook of virtual learning environments (pp. 117-158). Springer, Dordrecht.

Haraway DJ (2016) Staying with the Trouble: Making Kin in the Chthulucene. Durham: Duke University Press.

Holgate, B (2019) Climate and Crises: Magical Realism as Environmental Discourse. London and New York: Routledge.

Jeffrey S (2016) The Posthuman Body in Superhero Comics: Human, Superhuman, Transhuman, Post/Human. London \& New York: Palgrave MacMillan.

Kallis G (2011) In defence of degrowth. Ecological economics, 70(5): 873-880.

Kennedy C and Lukinbeal C (1997) Towards a holistic approach to geographic research on film. Progress in Human Geography 21(1): 33-50.

King E and Page J (2017) Posthumanism and the Graphic Novel in Latin America. London: UCL Press.

Klein R (2013) 'Climate Change through the Lens of Nuclear Criticism'. Diacritics 41.3: 82-87.

Latour B (1993) We have never been modern. Harvard University Press.

Latour B (2015) Telling friends from foes in the time of the Anthropocene. In The Anthropocene and the global environmental crisis (Vol. 145, No. 155, pp. 145-155). Routledge in association with GSE Research.

Lawson M and Martin M (2018) The Commitment to Reducing Inequality Index 2018: A global ranking of governments based on what they are doing to tackle the gap between rich and poor.

Lewis SL and Maslin MA (2015) 'A Transparent Framework for Defining the Anthropocene Era'. The Anthropocene Review 2(2): 128-146.

Lukinbeal C and Zimmermann S (2006) Film geography: A new subfield. Erdkunde 60: 315-325.

McCloud S (1993) Understanding Comics: The Invisible Art. New York: HarperCollins Publishers, Inc.

McGuire R (2014) Here. London: Penguin Books.

Menga F and Swyngedouw E (2018) States of water. In Menga F and Swyngedouw E (eds) Water, Technology and the Nation-State (pp. 1-18). Routledge.

Mertens M and Craps S (2018) 'Contemporary Fiction vs. the Challenge of Imagining the Timescale of Climate Change'. Studies in the Novel 50(1): 134-153.

Mickwitz N (2016) Documentary Comics: Graphic Truth-Telling in a Skeptical Age. London \& New York: Palgrave MacMillan. 
Miller G, Lathouris N and Sexton M (2015) Mad Max: Fury Road. Burbank, California: DC Comics.

Miller G (2015) Mad Max: Fury Road. Burbank, California: Warner Bros. Pictures.

Mirzoeff N (2014) 'Visualising the Anthropocene'. Public Culture 26(2): 213-232.

Monbiot G (2017) Out of the Wreckage: A New Politics for an Age of Crisis. London \& New York: Verso.

Moncion L (2017) ‘Time Frames: Graphic Narrative and Historiography in Richard McGuire's Here'. Imaginations 7(2) 199-213.

Moretti F (2006) The Novel, Volume 1. Princeton, NJ: Princeton University Press.

Morton T (2013) Hyperobjects: Philosophy and Ecology after the End of the World. Minneapolis: University of Minnesota Press.

Nixon R (2011) Slow Violence and the Environmentalism of the Poor. Harvard: Harvard University Press.

Nixon R (2014) 'The Anthropocene: The Promise and Pitfalls of an Epochal Idea'. Edge Effects, 6 November. Web. http://edgeeffects.net/anthropocene-promise-and-pitfalls/ (accessed 1 May 2019).

Onal F (2015) 'What can Mad Max tell us about water scarcity?’ New Internationalist, 29 May. Web. https://newint.org/blog/2015/05/29/mad-max-water-scarcity (accessed 9 April 2019).

Perry L (2018) 'Anthroposcenes: Towards an Environmental Graphic Novel'. C21 Literature: Journal of 21st-Century Writings 6(1).

Pesse MW (2019) “"So shiny, so chrome": images and ideology of humans, machines, and the Earth in George Miller's Mad Max: Fury Road'. Cultural Geographies 26(1): 43-55.

Pinker S (2019) Enlightenment now: The case for reason, science, humanism, and progress. Penguin Books.

Robbins P and Marks B (2010) Assemblage geographies. Smith, S., Pain, R., Marston, S. and Jones III, JP (eds) Sage Handbook of Social Geographies. Sage: London, 176-194.

Rockström J, Steffen W, Noone K, Persson Å, Chapin III FS, Lambin EF, Lenton TM, Scheffer M, Folke C, Schellnhuber HJ, Nykvist B (2009) A safe operating space for humanity. Nature 461: 425475.

Rodriguez D (2018) 'Narratorhood in the Anthropocene: Strange Stranger as Narrator-Figure in The Road and Here'. English Studies 99(4): 366-382.

Roelvink G and Zolkos M (2011) Climate change as experience of affect. Angelaki, 16(4): 43-57.

Schlosser K (2015) Apocalyptic imaginaries, Gramsci, and the last man on Earth. GeoHumanities 1: 14 .

Smailbegović A (2015) 'Cloud Writing: Describing Soft Architectures of Change in the Anthropocene'. In Heather Davis and Etienne Turpin eds., Art in the Anthropocene: Encounters Among Aesthetics, Politics, Environments and Epistemologies. London: Open Humanities Press, pp.93-108. 
Strauss K (2015) These overheating worlds. Annals of the Association of American Geographers 105(2): 342-350.

Swyngedouw E (1999) Modernity and hybridity: nature, regeneracionismo, and the production of the Spanish waterscape, 1890-1930. Annals of the association of American Geographers 89(3): 443465 .

Swyngedouw E (2013) Apocalypse now! Fear and doomsday pleasures. Capitalism Nature Socialism 24(1): 9-18.

Trexler A (2015) Anthropocene Fictions: The Novel in a Time of Climate Change. Charlottessville: University of Virginia Press.

Ware C (2014) 'Chris Ware on Here by Richard McGuire - a game-changing graphic novel'. The Guardian, 17 December. https://www.theguardian.com/books/2014/dec/17/chris-ware-here-richardmcguire-review-graphic-novel (accessed 13 May 2019).

Whatmore S (2002) Hybrid Geographies: Natures Cultures Spaces. London: Sage.

Whatmore S (2004) Humanism's excess: some thoughts on the'posthuman/ist'agenda. Environment and Planning A 36(8): 1360-1363.

Williams P (2011) Race, Ethnicity and Nuclear War: Representations of Nuclear Weapons and Post-Apocalyptic Worlds. Liverpool University Press.

Wolfe C (2010) What is posthumanism? University of Minnesota Press.

Yusoff K and Gabrys J (2011) Climate change and the imagination. Wiley Interdisciplinary Reviews: Climate Change 2(4): 516-534.

Yusoff K (2018) A Billion Black Anthropocenes or None. Minneapolis: University of Minnesota Press. 